\title{
Comparison of Socio-Demographic and Clinical Features of Bipolar Patients With And Without Obsessive Compulsive Disorder
}

\author{
Arvin Hedayati ${ }^{1}$, Ali Javadpour ${ }^{1}$, Amir Bazrafshan ${ }^{1}$, Arash Mani ${ }^{2}$, Amin Azizi ${ }^{3}$
}

\section{ÖZET:}

Obsesif kompülsif bozuklug̃u olan ve olmayan iki uçlu bozukluk hastalarının klinik ve sosyodemograifk özelliklerinin karșılaștırılması

Amaç: Epidemiyolojik çalıșmalar iki uçlu bozuklug̃u olan hastalarda obsesif kompülsif bozuklug̃un hayat boyu yaygınlıg̃ının \%3.2 ile \%35 arasında oldug̃unu göstermektedir. Bu arada iki uçlu bozuklug̃un obsesif kompülsif bozukluk ile birlikte oldug̃u (IUB-OKB) ve olmadiagı (saf iUB) hastalarla yapılan ve hastaların demografik ve klinik özelliklerini deg̃erlendiren birkaç çalıșmanın yayınlanan sonuçları tartışmalıdır. Bu çalışmanın amacı iki uçlu bozukluk hastalarından OKB ekhastalıg̃ı olan ve olmayanların sosyodemografik ve klinik özelliklerini karşıșştırmaktır. Yöntem: DSM-IV Eksen I Bozuklukları için Yapılandııılmıș Psikiyatrik Görüșme Formu (SCID-I) ile tanı konmuș 204 yatan hastanın katıldıg̃ı kesitsel, basit yapılı hastane kaynaklı bir çalıșmadır. Demografik ve klinik deg̃ișkenler Yale-Brown obsesyon kompulsiyon ölçeg̃i, Bech-Rafaelsen mania ölçeg̃i ve Hamilton depresyon ölçeg̃inden elde edildi.

Bulgular: iki uçlu bozuklug̃u (IUB) olan 204 hastadan saf iUB'si olan $123(\% 60.3)$ ve iUB-OKB'si olanlar ise 81 $(\% 39.7)$ idi. İUB-OKB ve saf iUB grupları arasında eg̃itim $(p=0.036)$ ve medeni durumlarında $(p=0.022)$ önemli farklııklar vardı. Gruplar karşılaștıııldı̃ında klinik özelliklerden: intihar düș̈̈ncesi, yatkınlı̃̃ı ve girișimleri $(p=0.000)$; bașvuru sıklı̃̃ı ( $p=0.044)$; madde kötüye kullanım öyküsü $(p=0.001)$, ailede OKB öyküsü $(p=0.000)$; ailede duygudurum bozuklug̃u öyküsü ( $p=0.036)$ önemli farklılıklar göstermekteydi. Sonuç: IUB ve OKB ekhastalıg̃ının belirgin demografik ve klinik özelliklerinin olması tanısal ve tedavi açısından farklı yaklaşımlara ihtiyacı olabilecek özel bir iki uçlu bozukluk tipi olabileceg̃i izlenimini uyandırmaktadır. ilerideki çalısmalar bu alandaki bilgilerimizi artırmamıza yardımcı olabilir.

Anahtar sözcükler: iki uçlu bozukluk, ekhastalık, obsesif kompülsif bozukluk

Journal of Mood Disorders 2011;1(4):145-51

\section{ABSTRACT:}

Comparison of socio-demographic and clinical features of bipolar patients with and without obsessive compulsive disorder

objective: Recent epidemiological studies have shown that lifetime prevalence of obsessive compulsive disorder (OCD) in bipolar patients range from $3.2 \%$ to $35 \%$. Meanwhile, few studies have evaluated demographic and clinical features of bipolar disorder (BD) with OCD (BD-OCD) and $B D$ without $O C D$ (pure $B D$ ), and the published results of such studies have been controversial. The aim of the current study was to compare the socio-demographic and clinical characteristics of $B D$ patients with and without $O C D$ Methods: In a cross-sectional, simple convenient hospitalbased study, 204 bipolar inpatients diagnosed based on Structured Clinical Interview for DSM-IV (SCID) were recruited. Demographic and clinical variables were obtained by using the Yale-Brown obsessive compulsive scale, Bech-Rafaelsen Mania Scale, and Hamilton Depression scale.

Results: Out of 204 patients with BD, 123 (60.3\%) patients had pure BD and 81 (39.7\%) had BD-OCD. There were significant differences between BD-OCD and pure BD group in terms of education $(p=0.036)$ and marital status $(p=0.022)$. Of clinical features, suicidal thoughts, tendencies, and attempts $(p=0.000)$, frequency of admission $(p=0.044)$, history of substance abuse $(p=0.001)$, family history of $O C D(p=0.000)$, and family history of mood disorder $(p=0.036)$ were significantly different between the groups.

Conclusions: Distinct demographic and clinical characteristics of bipolar patients with $O C D$ comorbidity suggest a specific type of bipolar mood disorder which might need a different diagnostic and therapeutic management. Further longitudinal studies may assist in enhancing our knowledge in this field.

Key words: bipolar disorder, comorbidity, obsessivecompulsive disorder

Journal of Mood Disorders 2011;1(4):145-51
${ }^{1} \mathrm{MD}$, Research center for Psychiatry and Behavioral Science, Shiraz University of Medical Sciences, Shiraz, Iran ${ }^{2} \mathrm{PhD}$, Research center for Psychiatry and Behavioral Science, Shiraz University of Medical Sciences, Shiraz, Iran ${ }^{3} \mathrm{BC}$, Shiraz University of Medical Sciences, Ebne-Sina Hospital, Shiraz, Iran

Yazıșma Adresi / Address reprint requests to: Arvin Hedayati, Research Center for Psychiatry and Behavioral Science, Shiraz University of Medical Sciences, Department of Psychiatry, Hafez Hospital, Shiraz, Iran

Telefon / Phone: +98-711-627-9319 Elektronik posta adresi / E-mail address: dr.arvinhedayati@gmail.com

Kabul tarihi / Date of acceptance: 17 Aralık 2011 / December 17, 2011

Bag̃ıntı beyanı

A.H., A.J., A.B., A.M., A.A.: Yazarlar bu makale ile ilgili olarak herhangi bir çıkar çatısmas bildirmemișlerdir.

\section{Declaration of interest:}

A.H., A.J., A.B., A.M., A.A.: The authors reported no conflict of interest related to this article.

\section{INTRODUCTION}

Until the $19^{\text {th }}$ century, it was thought that comorbidity of bipolar disorder (BD) and obsessive compulsive disorder $(\mathrm{OCD})$ is rare and few studies had reported the comorbidity of bipolar disorder with obsessive compulsive disorder (BD-OCD) (1). Recent epidemiological studies, however, have shown that lifetime prevalence of OCD in bipolar patients ranges from $3.2 \%$ to $35 \%$ (2-4).

There is some evidence that comorbidity of anxiety 
disorders with bipolar disorder is associated with certain demographic and clinical characteristics of patients. It has been reported that comorbidity of anxiety disorders is common in male patients with early onset of the BD and poor educational achievement. Their response to psychotropic drugs is poor and prevalence of psychotic episodes, mixed episodes of disorder, suicide attempts and substance abuse are high. This comorbidity is related to more hospitalizations and prolonged episodes as well (4-7).

Although a lot of work has been performed on comorbidity of anxiety disorders and bipolar disorder, our knowledge of comorbidity of OCD and BD is trivial. There are limited studies which evaluate the relationship between BD and OCD. Likewise, few studies have been conducted to evaluate demographic or clinical features of BD-OCD and the published results of such studies have been controversial. Magalhaes et al. showed that BD patients with lifelong history of OCD reported more suicide attempts, alcohol abuse, and rapid cycling episodes than bipolar patients without an anxiety disorder. Also BD-OCD patients reported a lower quality of life than pure BD (8). In 2002, Perugi reported higher rate of substance abuse in BD-OCD patients (9). Tukel et al. showed that there were no significant differences in marital status, education, suicide attempts, and rapid cycling between those patients with pure BD and the ones with BD-OCD (10). The findings of the earlier studies revealed a high rate of family history of obsessive compulsive disorder in BD-OCD's probands, suggesting that hereditability plays an important role in the comorbidity of OCD with bipolar disorder (10). Although it seems that $\mathrm{BD}-\mathrm{OCD}$ can be defined as a specific category of BD, our knowledge of the relation between BD and OCD is limited and inconsistent. Therefore we designed this study to evaluate and compare the demographic and clinical characteristics of pure BD and BD-OCD patients.

\section{METHODS}

This cross-sectional, hospital-based study was conducted for a period of 6 months from March 1, 2011 to August 30, 2011. In a simple convenient sampling method, 228 bipolar inpatients were screened. The patients were included if they were between 18 and 65 years of age. Also the exclusion criteria included the presence of other psychiatric comorbidity (such as schizophrenia, schizoaffective, post-traumatic stress disorder...), mental retardation, disabling medical conditions, and cognitive disorders. All participants signed the informed consent form prior to study and the study was approved by the ethics committee of the university.

All of the patients answered the questions in the sociodemographic questionnaire about age, gender, level of education, employment, and marital status. Clinical characteristics such as age of onset of BD, age of onset of OCD, frequency of hospitalizations, substance use, history of suicidal thoughts and attempts, and family history of mood disorders and OCD were obtained from patients, their relatives, and also from previous medical records.

A senior psychiatry resident (AH) interviewed all the subjects based on the Structured Clinical Interview for DSM-IV (SCID), to confirm the diagnosis. The patients were divided into two groups: thepatients who did not have obsessive compulsive disorder (pure BD) and those who had obsessive compulsive disroder in conjunction with bipolar disorder (BD-OCD).

The Bech-Rafaelsen Mania Rating Scale (11) and the Hamilton Depression Rating Scale (12) were used to assess the type and severity of the current mood episode. In the BD-OCD patients, severity and type of obsessive compulsive symptoms were defined using Yale-Brown Obsessive Compulsive Scale.

Statistical analysis was performed using the Statistical Package for Social Sciences (SPSS) version 17.0. Chi square and t test were used for comparison of the data. All $P$ values were 2 tailed, and statistical significance was set at $\mathrm{P}<.05$.

\section{INSTRUMENTS}

\section{Bech-Rafaelsen Mania Scale}

It is a clinician-rated symptom scale designed to assess the presence and severity of clinical features of mania and hypomania and the effectiveness of therapeutic interventions for bipolar disorder. This questionnaire assesses 11 items including elevated mood, pressured speech, increased social contact, increased motor activity, sleep disturbances, social activities and distractibility, hostility and irritability, increased sexual activity, increased self-esteem, flight of thoughts, and noise level of speech and 
other vocal activities. Each item is scored on a scale of 0 to 4. The total score has been standardized so that scores $<15$ indicate hypomania, scores around 20 indicate moderate mania, and scores around 28 indicate severe mania (11).

\section{Hamilton Depression Scale (HAM-D)}

The 24-item version of HAM-D questionnaire was used to check depressive symptoms. Items on the HAM-D are scored from 0 to 2 or from 0 to 4 , with the total score ranging from 0 to 50 . Scores of 7 or less may be considered normal; 8 to 13 , mild; 14 to 18 , moderate; 19 to 22 , severe; and 23 and above, very severe. The HAM-D was designed for clinician raters but has been completed by trained lay administrators as well. Ratings are completed by the examiner based on the patient interviews and observations (12).

\section{Yale-Brown Obsessive-Compulsive Scale}

The Yale-Brown Obsessive-Compulsive Scale (YBOCS) was developed in the late 1980s to measure the severity of symptoms in OCD. It has ten items rated based on a semistructured interview. The first five items concern obsessions including the amount of time that they consume, the degree to which they interfere with normal functioning, the distress that they cause, the patient's attempts to resist them, and the patient's ability to control them. Theremaining five items ask parallel questions about compulsions. Each item has a set of item-specific anchors scored from 0 to 4 , so the total scores for obsessions and compulsions each range from 0 to 20 and the overall total score ranges from 0 to 40 . Before the first use of the YBOCS, an associated 64-item checklist is administered to provide a more detailed assessment of the specific content of the patient's obsessions and delusions (12). These 64 items are classified into 14 categories. Its score is defined as follows: $0-7=$ sub clinical; $8-15=$ mild; $16-23=$ moderate; 24-31=severe; $32-40=$ extreme (13).

\section{RESULTS}

Two hundreds and twenty eight inpatients with bipolar disorder were screened. Twenty four of them were excluded, as 6 patients did not meet the inclusion criteria and the remaining 18 patients did not sign the informed consent forms. Finally 204 BD patients with a mean age of 24.1 years, including 108 female (53\%) and 96 male (47\%) left for analyses.

Of 204 bipolar patients, $60.3 \%$ had pure BD $(n=123)$ and $39.7 \%$ had BD-OCD $(n=81)$.There was a significant

Table 1: Comparison of demographic features among pure BD and BD-OCD

\begin{tabular}{|c|c|c|c|}
\hline Demographic data & $\begin{array}{l}\text { Pure BD } \\
\text { n (\%) }\end{array}$ & $\begin{array}{l}\text { BD-OCD } \\
\text { n }(\%)\end{array}$ & $P$ value \\
\hline Age & & & 0.191 \\
\hline $18-30$ & $61(49.6 \%)$ & $50(61.7 \%)$ & \\
\hline $31-40$ & $38(30.9 \%)$ & $18(22.2 \%)$ & \\
\hline $41-50$ & $11(8.9 \%)$ & $3(3.7 \%)$ & \\
\hline $50<$ & $13(10.6 \%)$ & $10(12.3 \%)$ & \\
\hline Gender & & & 0.800 \\
\hline Male & $57(46.3 \%)$ & $39(48.1 \%)$ & \\
\hline Female & $66(53.7 \%)$ & $42(51.9 \%)$ & \\
\hline Marital status & & & 0.022 \\
\hline Married & $81(65.9 \%)$ & $38(46.9 \%)$ & \\
\hline Single & $38(30.9 \%)$ & $37(45.7 \%)$ & \\
\hline Divorced or separated & $4(3.3 \%)$ & $6(7.4 \%)$ & \\
\hline Education & & & 0.036 \\
\hline Illiterate & $4(3.3 \%)$ & $3(3.7 \%)$ & \\
\hline Elementary & $37(30.1 \%)$ & $39(48.1 \%)$ & \\
\hline Diploma & $54(43.9 \%)$ & $30(37 \%)$ & \\
\hline Academic & $28(22.8 \%)$ & $9(11.1 \%)$ & \\
\hline Job & & & 0.787 \\
\hline House wife & $41(33.3 \%)$ & $29(35.8 \%)$ & \\
\hline Employed & $51(41.5 \%)$ & $29(35.8 \%)$ & \\
\hline Unemployed & $25(20.3 \%)$ & $20(24.7 \%)$ & \\
\hline Retired & $6(4.9 \%)$ & $3(3.7 \%)$ & \\
\hline
\end{tabular}


Table 2: Comparison of clinical features among pure BD and BD-OCD

\begin{tabular}{llll} 
Clinical data & $\begin{array}{l}\text { Pure BD } \\
\mathbf{n}(\%)\end{array}$ & $\begin{array}{l}\text { BD-0CD } \\
\mathbf{n}(\mathbf{\%})\end{array}$ & P value \\
\hline $\begin{array}{l}\text { Age of onset mood disorder } \\
\quad<18\end{array}$ & $18(14.6 \%)$ & $18(22.2 \%)$ & 0.011 \\
$18-30$ & $87(70.7 \%)$ & $49(60.5 \%)$ & \\
$31-45$ & $17(13.8 \%)$ & $7(8.6 \%)$ & \\
$45<$ & $1(0.8 \%)$ & $7(8.6 \%)$ & 0.001 \\
Substance abuse & $19(15.4 \%)$ & $29(35.8 \%)$ & 0.000 \\
History of suicide attempt & $33(26.8 \%)$ & $48(59.3 \%)$ & 0.036 \\
Family history of mood disorder & $56(45.5 \%)$ & $49(60.5 \%)$ & 0.000 \\
Family history of OCD & $21(17.1 \%)$ & $42(51.9 \%)$ &
\end{tabular}

Table 3: Distribution of obsessive and compulsive symptoms in BMD-OCD subjects

\begin{tabular}{ll} 
Type & \% \\
\hline Contamination Obsessions & 42 \\
Aggressive Obsessions & 30.9 \\
Somatic Obsessions & 22.2 \\
Religious Obsessions & 16 \\
Miscellaneous Obsessions & 14.8 \\
Sexual Obsessions & 11.1 \\
Obsession with Need for Symmetry or Exactness & 7.4 \\
Hoarding / Collecting Obsessions & 4.9 \\
Cleaning / Washing Compulsions & 56.8 \\
Checking Compulsions & 48.1 \\
Repeating Compulsions & 19.8 \\
Counting Compulsions & 18.5 \\
Ordering / Arranging Compulsions & 16 \\
Miscellaneous Compulsions & 13.6 \\
Hoarding / Collecting Compulsions & 1.2
\end{tabular}

difference between both groups in terms of marital status $(\mathrm{P}=0.022)$ and education $(\mathrm{P}=0.036)$. Pure $\mathrm{BD}$ patients were two times more likely to be married and more educated as compared to BD-OCD individuals. There was no statistically significant difference between BD-OCD and pure BD patients in terms of age $(0.191)$, gender $(0.800)$, and employment (0.787), (see Table 1).

The severity of BD is evaluated by frequency of admissions and severity of manic and depressive symptoms in current episode of bipolar disorder. There was no statistically significant difference between BD-OCD and pure BD regarding severity of current mood episode. The mean of number of hospitalizations in BD-OCD patients was significantly higher than that in the pure BD (2.4 and 1.86, respectively), ( $\mathrm{p}=0.036)$.

The mean of age of onset of first mood episode in pure BD and BD-OCD patients was similar (34.36 and 34.33, respectively). There was a significant difference between both groups in terms of substance abuse $(\mathrm{P}=0.001)$ and history of suicidal attempts $(\mathrm{P}=0.000)$. Substance abuse and suicide attempts were higher in BD-OCD patients than pure $\mathrm{BD}$ ones.

The rate of family history for mood disorders $(\mathrm{P}=0.036)$ and obsessive compulsive disorder $(\mathrm{P}=0.000)$ was higher in BD-OCD patient's relatives than pure BD. Table 2 presents clinical variables of both groups. In BD-OCD patients, $80.2 \%$ reported the onset of obsessive compulsive symptoms prior to the first mood disorder episode. Also $27.2 \%, 46.9 \%$, and $25.9 \%$ had mild, moderate, and severe or very severe OCD symptoms, respectively.

Fifteen domains of obsessive and compulsive symptoms were detected in BD-OCD patients. Among the obsessions, contamination type (42\%) and aggressive thoughts $(30.9 \%)$ were the most common. Washing compulsion (56.8\%) and checking (48.1\%) were also the most common compulsions. Hoarding thoughts were the least common type of obsession (4.9\%). Among compulsions, the least common type was related to the acts of hoarding (1.2\%), (See Table 3 ).

\section{DISCUSSION}

Our objective in this study was to compare the demographic and clinical characteristics of pure bipolar patients and bipolar patients with obsessive compulsive disorder. The socio-demographic characteristics contained information about age, gender, marital status, and socioeconomic factors, which were based on income, education, occupation, and wealth; and the clinical characteristics included information about age of onset of BD, severity of current episode of mood disorder, history of substance use, history of suicidal thoughts and 
attempts, comorbid medical disorders, and family history for BD and OCD.

In the present study, lifetime prevalence of OCD among inpatients with bipolar disorder was $39.7 \%$. In previous studies, the rate of co-morbidity has ranged from $3.2 \%$ to $35 \%(14,15)$. This discrepancy in results could be due to different methodological approaches such as involvement of inpatients or outpatients, utilization of epidemiological or clinical data, assessment method used in the diagnosis, and evaluation of the presence of lifetime or current comorbidity.

Data from the current study revealed no significant difference between the two groups in terms of age and gender, which is in line with the findings of the earlier studies that showed no significant differences between BD-OCD and pure BD in terms of age and gender $(10,14)$.

In the present research, fewer of BD-OCD subjects were married in comparison with pure bipolar group which is inconsistent with the findings of previous studies $(8,14)$. This difference could be related to various sampling of these studies or impact of social and cultural factors.

Our data for evaluation and comparison of socioeconomic status were limited to the patients' education and employment. In contrast to previous studies that showed no significant difference between BD-OCD and pure BD groups in terms of education $(8,10,14)$, in our study pure BD patients were more educated than BD-OCD.

Inconsistent with other studies, employment status was not significantly different between 2 groups suggesting that the presence of obsessive symptoms did not affect the job performance of patients $(10,14)$. In our study, the difference in the age of the onset of $\mathrm{BD}$ was significant between the two groups although the age of the onset of $\mathrm{BD}$ in majority of the patients in both groups was between 18 to 30 years. This is in contrast to the findings of Koyuncu's study (10), in which there were no statistically significant differences between BD-OCD and pure BD groups in terms of the age of $\mathrm{BD}$ onset. Bias in recalling of the first episode of mood disorder might be an explanation of this difference as subjects in this study rely on their subjective memory to report the definite time of the onset of the symptoms.

In the present study, positive family history for OCD in BD-OCD patients was higher than pure BD patients. Only one earlier investigation supports our results (10). The finding of these studies is still not conclusive enough to consider the role of genetic factors in classification of $\mathrm{BD}$ with obsessive symptoms and BD without obsessive compulsive disorder.

Zutshi et al. comparing pure BD, BD-OCD, and nonbipolar OCD noted a higher rate of mood disorder in relatives of BD-OCD subjects than the obsessive compulsive disorder group (15). The findings of the current study showed that the rate of substance abuse is higher in BD-OCD patients than those with pure BD. This is in line with Perugi's study (9). On the other hand, in a research conducted by Koyuncu et al., there was not significant difference between both groups for alcohol use (10). In Magalhaes' study, while the rate of alcohol dependence was significantly different between both groups, there was no significant differences for other substances (8). This can be related to the patients' affinity in reporting substance abuse in different cultures; also, it depends on the evaluation of alcohol and substance abuse in 1 or 2 separate fields. In sum, the findings of these studies are not conclusive; further studies are recommended.

In a recent study, BD-OCD patients reported more suicidal thoughts and attempts than pure BD patients. The data from studies conducted by Chen, Krüger and Magalhaes also reported a higher incidence of prior suicide attempts in BD-OCD than pure bipolarpatients $(7,8,17)$. This may be due to more suffering of obsessive compulsive symptoms seen in BD-OCD patients.

Severity of BD is evaluated by the frequency of admissions and severity of manic and depressive scale. In this study, BD-OCD patients had a higher rate of hospitalization than pure BD cases. Darby et al. in their study described that compared with pure BD, patients with comorbid bipolar affective disorder required a greater number of outpatient appointments, had a greater number of hospital admissions, were more likely to have been allocated a care coordinator and to have received psychological support (18).

The present study showed that in BD-OCD patients the onset of OCD was prior to BD. In a study by Issler on a sample of women with bipolar disorder, a significant proportion of subjects reported onset of their OCD symptoms from their childhood (19). The results of Masi et al.'s study replicated this finding (20). The high rate of earlyonset OCD among BD patients suggests a distinct subtype.

The most common types of obsessions among 
BD-OCD patients were contamination and aggressive thoughts, and the most common compulsions were washing and checking. Hoarding thoughts and acts were the least common types of obsession and compulsion, respectively. The findings of Issler et al.'s study showed that aggressive thoughts, symmetry, and contamination were the most common forms of obsessions, and washing and checking were the most common of compulsions, while hoarding was the least common obsession (18). Zutshi et al. in their study reported that the most common types of obsessions in BD-OCD patients were pathological doubt (50\%), other obsessions (43\%), contamination (36\%), and sexual obsession (32\%) and among compulsions, checking (46\%), other types (43\%), and cleaning $(32 \%)$ were the most common types. Hoarding thoughts were the least type among obsessions (1\%). In compulsions hoarding acts beside ordering were the least common types (1\%)(15). Our data are not in agreement with Masi et al.'s findings reporting more philosophical, existential, bizarre, and superstitious obsessions with less ordering compulsions among children and adolescents with this comorbidity (20). Moreover the findings of present study differ from Perugi et al's study, which described predominance of religious and sexual obsessions with less checking rituals among OCD and BMD patients (21). Maaroofi's findings are also different from our research. Although no definite cause can be described for the difference, these disagreements may be due to different methods of reporting.

There was no statistically significant difference between BD-OCD and pure BD groups in terms of age and gender. These similarities can be considered as significant with respect to the validity of our study.

When clinical features of BD patients with or without comorbid OCD were compared, there were statistically significant differences in terms of the mean of age of BD

\section{References:}

1. Annigeri B, Raman R, Appaji R. Obsessive compulsive disorder with bipolar mood disorder: A rare comorbidity in India. Indian J Psychol Med. 2011;33:83-85.

2. Strakowski SM, Tohen M, Stoll AL, Faedda Gl, Goodwin DC. Comorbidity in mania at first hospitalization. Am J Psychiatry 1992; 149: 554-556.

3. Boylan KR, Bieling PJ, Marriott M, Begin H, Young LT, MacQueen GM. Impact of comorbid anxiety disorders on outcome in a cohort of patients with bipolar disorder. J Clin Psychiatry. 2004; 65:1106-13. onset, history of suicide attempts, and hospitalizations. This suggests that comorbid OCD might have a unique place with respect to its effects in bipolar patients. Fagiolini et al. have discussed how pervasive anxiety comorbidity may characterize a distinctive class of patients with BD (22). It seems that OCD-BD can also be defined as a specific type of $\mathrm{BD}$, with characteristics different from those of pure BD. Although the nature of the relationship between $\mathrm{BD}$ and $\mathrm{OCD}$ is still unknown, OCD association may imply an alternative expression of the other. This specific feature is related to different treatments (23).

One of the main limitations of our study was assessment of some variables based on retrospective recall. We only evaluated $\mathrm{BD}$ I. Also, diagnosis of OCD in BD patients was done by DSM-IV-TR criteria of OCD, whose reliability and validity are not documented for BD-OCD. Meanwhile, it is not easy to clearly define OCD in $\mathrm{BD}$ as it may occur at different stages of disorder.

Despite the methodological limitations, this study produced challenging data about the clinical and sociodemographic aspects of OCD in a sample of bipolar inpatients whose data are recorded in their files, making it possible to re-evaluate these patients.

This study suggests a psychopathological relationship between BD and OCD. Further studies on epidemiologic, etiologic, genetic, and clinical aspects, as well as on treatment response, are necessary. Specially, using a longitudinal design may contribute to improving our understanding of the mechanisms of this association.

\section{Acknowledgments}

This research was supported by the Research Center for Psychiatry and Behavioral Science, Shiraz University of Medical Sciences.
4. Simon NM, Otto MW, Wisniewski SR, Fossey M, Sagduyu K, Frank E, Sachs GS, Nierenberg AA, Thase ME, Pollack MH. Anxiety disorder comorbidity in bipolar disorder patients: data from the first 500 participants in the systematic treatment enhancement program for bipolar disorder (STEP-BD). Am J Psychiatry. 2004; 161:2222-2229.

5. Zutshi A, Kamath P, Reddy YC. Bipolar and non-bipolar obsessive compulsive disorder: a clinical exploration. Compr Psychiatry. 2007; 48:245-51 
6. Kruger S, Cooke RG, Hasey GM, Jorna T, Persad E. Comorbidity of obsessive compulsive disorder in bipolar disorder. J Affect Disord 1995;34:117-20

7. Chen YW, Dilsaver SC. Co-morbidity for obsessive compulsive disorder in bipolar and unipolar disorders. Psychiatry Res. 1995; 59:57-64

8. Magalhaes PV, Kapczinski NS, Kapczinski F. Correlates and impact of obsessive-compulsive comorbidity in bipolar disorder. Compre Psychiatry. 2010; 51:353-356.

9. Perugi G, Toni C, Frare F, Travierso MC, Hantouche E, Akiskal HS. Obsessive-compulsive-bipolar comorbidity: A systematic exploration of clinical features and treatment outcome. J Clin Psychiatry. 2002; 63:1129-1134.

10. Koyuncu A, Tükel R, Ozyildirim I, Meteris H, Yazici O. Impact of obsessive-compulsive disorder comorbidity on the sociodemographic and clinical features of patients with bipolar disorder. Compr Psychiatry. 2010; 51:293-7.

11. Bech P, Bolwig TG, Kramp P, Rafaelsen OJ: The Bech-Rafaelsen Mania Scale and the Hamilton Depression Scale. acta Psychiatrica Scandinavica.1979; 59:420-430.

12. Blacker D. Psychiatric rating scales. In Text book of Kaplan and Sadock's comprehensive text book of psychiatry, Sadock BJ,Sadock VA,Ruiz P(editors).Ninth edition., Wolters kluwer/ Lipincott Williams and Wilkins; 2009:1032-1059

13. Goodman WK, Price LH, Rasmussen SA, Mazure C, Fleischmann RL, Hill CL, Heninger GR, Charney DS. The Yale-Brown Obsessive Compulsive Scale. I. Development, use, and reliability. Arch Gen Psychiatry. 1989; 46:1006-11

14. Maroufi A, Goraishzadeh SM. Obsessive compulsive disorder in patients with bipolar I disorder and schizophrenia. Iranian journal of psychiatry and clinical psychology. 2004; 10:37-43.
15. Zutshi A, Kamath P, Reddy YC. Bipolar and nonbipolar obsessivecompulsive disorder: A clinical exploration. Compr Psychiatry. 2007; 48:245-251.

16. Raja M, Azzoni A. Clinical management of obsessive-compulsivebipolar comorbidity: a case series. Bipolar Disord. 2004; 6: 264-270

17. S. Kruger, P. Braunig and R.G. Cooke. Comorbidity of obsessivecompulsive disorder in recovered inpatients with bipolar disorder. Bipolar Disord. 2000; 2:71-74.

18. Darby L, Agius M, Zaman R. Co-morbidity of bipolar affective disorder and obsessive compulsive disorder in a Bedford community psychiatry team. Psychiatr Danub. 2011; 23:130-3.

19. Issler CK, Amaral JA, Tamada RS, Schwartzmann AM, Shavitt RG, Miguel EC, Lafer B. Clinical expression of obsessive-compulsive disorder in women with bipolar disorder. Rev Bras Psiquiatr. 2005; 27:139-142

20. Masi G, Perugi G, Toni C, Millepiedi S, Mucci M, Bertini N, Akiskal HS. Obsessive-compulsive bipolar comorbidity: Focus on children and adolescents. J Affect Disord. 2004; 78:175-183.

21. Perugi G, Akiskal HS, Pfanner C, Presta S, Gemignani A, Milanfranchi A, Lensi P, Ravagli S, Cassano GB. The clinical impact of bipolar and unipolar affective comorbidity on obsessivecompulsive disorder. J Affect Disord. 1997; 46:15-23.

22. Fagiolini A, Frank E, Rucci P, Cassano GB, Turkin S, Kupfer DJ. Mood and anxiety spectrum as a means to identify clinically relevant subtypes of bipolar I disorder. Bipolar Disord. 2007; 9:462-467.

23. Uguz F. Successful treatment of comorbid obsessive-compulsive disorder with aripiprazole in three patients with bipolar disorder. Gen Hosp Psychiatry. 2010; 32:556-8. 